\title{
An Investigation into the Ability of Certain $\alpha$-Haemolytic Micrococci to Form Lactic Acid from D-Glucose
}

\author{
By O. J. TJELTVEIT AND O. G. CLAUSEN \\ University of Oslo, Institute of Pharmacy, Department of \\ Bacteriology, Blindern, Norway
}

(Received 10 June 1963)

\section{SUMMARY}

The ability of some $\alpha$-haemolytic micrococci described by Clausen (1964) to form lactic acid from glucose has been determined by means of 'resting' bacterial cells. The total quantity of lactic acid was measured in each individual test. Reference organisms used were a strain of Aerococcus viridans, 2 enterococcus strains, and 1 strain of Staphylococcus epidermidis. Glucose conversion was found to be in large measure dependent upon the concentration of active bacterial cells in the suspension. All the $\alpha$-haemolytic micrococcus strains tested, together with the reference strains, proved to be homofermentative or near homofermentative formers of lactic acid, provided that the number of active organisms was brought to a sufficiently high level in the suspension when converting the glucose.

\section{INTRODUCTION}

This work constitutes a supplement to an investigation by Clausen (1964) into localization, identification, and classification of eleven strains of $\alpha$-haemolytic micrococci and deals with their formation of lactic acid. Culturally and morphologically these bacterial strains appear to be closely akin to the $\alpha$-haemolytic micrococci described by Shaw, Stitt \& Cowan (1951), and, subsequently, by Williams, Hirch \& Cowan (1953), who named them aerococci. In regard to important biochemical properties, however, most of Clausen's strains differ from these aerococci.

This paper includes a description of the method employed to determine the formation of lactic acid from glucose by the micrococci and aerococci and various reference bacteria. Conversion of glucose was carried out by means of 'resting' bacterial cells (Quastel \& Whetham, 1924). The total quantity of lactic acid was measured in each experiment, but further investigation into the specific rotation of the acid was not made.

\section{METHODS}

Bacteria. The eleven $\alpha$-haemolytic micrococci strains and the following reference strains: Aerococcus viridans (NCTC 8251), Streptococcus faecalis, S. faecalis var. zymogenes, and Staphylococcus epidermidis.

Media, culture, and pre-treatment

One solid medium was used, $5 \%$ citrated horse blood agar, which consisted of $1 \%$ peptone (Danish, Orthana Bacteriological Brand), 0.3\% NaCl, 0.2 \% $\mathrm{Na}_{2} \mathrm{HPO}_{4}$ 
and $1.8 \%$ agar (Japanese, quality Kobe $\mathbf{I}$ ) in ordinary aqueous beef infusion $(\mathrm{pH}=\mathbf{7 \cdot 4})$.

The broth used was Pope trypsin broth prepared according to Graudal (1955).

All cultures were incubated aerobically at $37^{\circ}$.

\section{Method a}

Before use the bacterial strains were subcultured daily for 3 days on blood agar. A small inoculum (platinum loop) of strains 1-7 inclusive and the reference bacteria Aerococcus viridans, Streptococcus faecalis, and $S$. faecalis var. zymogenes (see Table 1) all of which grew well in Pope trypsin broth, was added to $50 \mathrm{ml}$. of trypsin broth; after $12 \mathrm{hr} 45 \mathrm{ml}$. of the culture were centrifuged (Graudal, 1955), the sediment washed three times in $15 \mathrm{ml}$. sterile saline, and the bacteria resuspended in $3 \mathrm{ml}$. of the same liquid. Strains 8-11 were also examined by this method.

The results are set out in Table 1 and in the lines marked ' $a$ ' in Table 2.

Table 1. Transformation of glucose into lactic acid by the $\alpha$-haemolytic micrococcus strains which grew well in trypsin broth

\begin{tabular}{|c|c|c|c|c|c|}
\hline Strains & $\begin{array}{l}\text { mg. glucose } \\
\text { transformed } \\
\text { from } 15 \mathrm{mg} \text {. }\end{array}$ & $\begin{array}{l}\% \text { glucose } \\
\text { transformed }\end{array}$ & $\begin{array}{l}\text { mg. lactic } \\
\text { acid formed }\end{array}$ & $\begin{array}{l}\text { mg. lactic } \\
\text { acid which } \\
\text { can be formed } \\
\text { theoretically }\end{array}$ & $\begin{array}{l}\text { Lactic acid } \\
\text { formed as } \\
\text { theoretical } \\
\text { quantity }\end{array}$ \\
\hline No. 1 & $13 \cdot 7$ & 91 & $11 \cdot 0$ & $13 \cdot 7$ & 80 \\
\hline No. 2 & $13 \cdot 9$ & 93 & $10 \cdot 8$ & $13 \cdot 9$ & 78 \\
\hline No. 3 & $14 \cdot 7$ & 98 & $12 \cdot 6$ & $14 \cdot 7$ & 86 \\
\hline No. 4 & 13.9 & 93 & $11 \cdot 3$ & $13 \cdot 9$ & 81 \\
\hline No. 5 & $14 \cdot 1$ & 94 & $11 \cdot 5$ & $14 \cdot 1$ & 82 \\
\hline No. 6 & $7 \cdot 0$ & 47 & $6 \cdot 6$ & $7 \cdot 0$ & 94 \\
\hline No. 7 & $12 \cdot 6$ & 84 & $10 \cdot 9$ & $12 \cdot 6$ & 86 \\
\hline Aerococcus viridans & $14 \cdot 3$ & 95 & $12 \cdot 0$ & $14 \cdot 3$ & 84 \\
\hline Streptococcus faecalis & 14.9 & 99 & $14 \cdot 6$ & $14 \cdot 9$ & 98 \\
\hline $\begin{array}{l}\text { S. faecalis var. zymo- } \\
\text { genes }\end{array}$ & $14 \cdot 9$ & 99 & $12 \cdot 1$ & $14 \cdot 9$ & 81 \\
\hline
\end{tabular}

Strains 8-11 and the reference strain Staphylococcus epidermidis (see Table 2), all of which showed poor growth in Pope trypsin broth, were adapted to this by daily subculture for 1 week. The results of subsequent investigations are tabulated in the lines marked b1 and b2 in Table 2, examination being carried out with bacterial suspensions obtained by the following methods:

Method b1: a small inoculum of the adapted bacterium was transferred to $50 \mathrm{ml}$. trypsin broth, which was incubated for $48 \mathrm{hr}$; then $45 \mathrm{ml}$. of the culture was centrifuged and the sediment washed and suspended in sterile saline solution as described under method a.

Method b2: $0.9 \mathrm{ml}$. trypsin broth culture at the final stage of the adaptation series was added to $90 \mathrm{ml}$. trypsin broth. After $15 \mathrm{hr}$ of incubation the culture was centrifuged and the sediment washed and suspended in sterile saline solution as described under method a.

\section{Glucose conversion}

$1 \mathrm{ml}$. of bacterial suspensions was transferred to each of two $10 \mathrm{ml}$. volumetric flasks, both of which contained $5 \mathrm{ml}$. phosphate buffer (Graudal, 1955), and one of 
which contained $0.3 \%$ glucose. The other flask served as a control. After gentle shaking to ensure thorough mixing, conversion proceeded in an incubator at $37^{\circ}$ over a period of $20 \mathrm{hr}$.

\section{Chemical analysis}

The solutions containing converted glucose were diluted to $10 \mathrm{ml}$. with distilled water and analysed. The glucose assay was performed according to the SomogyiNelson method (Somogyi, 1952). The lactic acid content was determined by the Barker and Summerson method (Barker \& Summerson, 1941).

\section{RESULTS}

The results of the analysis are set out in Tables 1 and 2. (Somogyi (1952) and Barker \& Summerson (1941) estimate the accuracy of the analytical methods used in this work as being about $\pm 5 \%$. The results of the investigations described are well within these limits.)

Table 2. Transformation of glucose into lactic acid by the $\alpha$-haemolytic micrococcus strains which showed poor growth in trypsin broth

\begin{tabular}{|c|c|c|c|c|c|c|}
\hline Strains & $\begin{array}{l}\text { Method } \\
\text { of } \\
\text { growth }\end{array}$ & $\begin{array}{l}\text { mg. glucose } \\
\text { transformed } \\
\text { from } \\
\mathbf{1 5 \cdot 0} \mathrm{mg} \text {. }\end{array}$ & $\begin{array}{c}\% \text { glucose } \\
\text { trans- } \\
\text { formed }\end{array}$ & $\begin{array}{l}\text { mg. lactic } \\
\text { acid formed }\end{array}$ & $\begin{array}{l}\text { mg. lactic } \\
\text { acid which } \\
\text { can be } \\
\text { formed } \\
\text { theoretically }\end{array}$ & $\begin{array}{l}\text { Lactic acid } \\
\text { formed } \\
\text { as } \% \\
\text { theoretical } \\
\text { quantity }\end{array}$ \\
\hline No. 8 & $\begin{array}{l}\mathrm{a} \\
\mathrm{b} 2\end{array}$ & $\begin{array}{r}5 \cdot 0 \\
14 \cdot 6\end{array}$ & $\begin{array}{l}33 \\
97\end{array}$ & $\begin{array}{r}3 \cdot 2 \\
13 \cdot 8\end{array}$ & $\begin{array}{r}5 \cdot 0 \\
14 \cdot 6\end{array}$ & $\begin{array}{l}64 \\
95\end{array}$ \\
\hline No. 9 & $\begin{array}{l}\text { a } \\
\text { b2 }\end{array}$ & $\begin{array}{r}2 \cdot 3 \\
14 \cdot 3\end{array}$ & $\begin{array}{l}15 \\
95\end{array}$ & $\begin{array}{r}0 \cdot 5 \\
13 \cdot 7\end{array}$ & $\begin{array}{r}2 \cdot 3 \\
14 \cdot 3\end{array}$ & $\overline{96}$ \\
\hline No. 10 & $\begin{array}{l}a \\
b 1 \\
\text { b2 }\end{array}$ & $\begin{array}{r}0 \cdot 9 \\
0 \cdot 3 \\
14 \cdot 2\end{array}$ & $\begin{array}{r}6 \\
\mathbf{2} \\
\mathbf{9 5}\end{array}$ & $\begin{array}{r}0 \cdot 3 \\
0 \cdot 2 \\
14 \cdot 0\end{array}$ & $\begin{array}{r}0 \cdot 9 \\
0 \cdot 3 \\
14 \cdot 2\end{array}$ & $\frac{-}{99}$ \\
\hline No. 11 & $\begin{array}{l}\mathrm{a} \\
\mathrm{b} 1 \\
\mathrm{~b} 2\end{array}$ & $\begin{array}{r}0 \cdot 6 \\
0 \cdot 2 \\
14 \cdot 2\end{array}$ & $\begin{array}{r}4 \\
1 \\
95\end{array}$ & $\begin{array}{c}0 \cdot 5 \\
0 \cdot 15 \\
12 \cdot 7\end{array}$ & $\begin{array}{r}0 \cdot 6 \\
0 \cdot 2 \\
14 \cdot 2\end{array}$ & $\overline{-}$ \\
\hline $\begin{array}{l}\text { hylococcus } \\
\text { lermidis }\end{array}$ & $\begin{array}{l}\text { a } \\
b_{1}\end{array}$ & $\begin{array}{l}0 \cdot 7 \\
5 \cdot 5\end{array}$ & $\begin{array}{r}5 \\
37\end{array}$ & $\begin{array}{l}0 \cdot 6 \\
4.5\end{array}$ & $\begin{array}{l}0 \cdot 7 \\
5 \cdot 5\end{array}$ & $\overline{82}$ \\
\hline
\end{tabular}

\section{DISCUSSION}

All the strains included in Table 1 caused high glucose conversion according to method a. The strains entered in Table 2, on the other hand, caused low glucose conversion both by method a and method b1; an exception was Staphylococcus epidermidis, which according to method b1 converted $37 \%$ of the glucose. The failure of method $a$ and $b l$ is thought to arise from the fact that the suspension of active organisms was too weak to bring about sufficiently rapid conversion of the glucose. In the bl method the suspension was concentrated enough, but it is probable that it contained a relatively large number of inactive organisms as a consequence of the prolonged period of incubation. Method b2 yielded abundant and active bacteria which caused extensive splitting of the glucose.

Lactic acid formation by these strains was found to range from 78 to $99 \%$ of the 
theoretically possible. Graudal (1955) characterizes a strain as homofermentative when the lactic acid formation is $80-100 \%$ of the theoretically possible.

With the $\alpha$-haemolytic micrococcus strains, the glucose conversion appears in large measure to depend on the number of active bacteria in the suspension. A sufficient number of such organisms cannot always be obtained by the commonly used methods of cultivation for investigation of lactic acid formation by enterococci.

All the bacterial strains examined in the course of this work proved to be formers of lactic acid, and must be regarded as being homofermentative or near homofermentative.

\section{REFERENCES}

Barker, S. B. \& Summerson, W. H. (1941). The colorimetric determination of lactic acid in biological material. J. biol. Chem. 138, 535.

Clausen, O. G. (1964). The discovery, isolation and classification of various $\alpha$-haemolytic micrococci which resemble aerococci. J. gen. Microbiol. 34, 333.

GraUdal, H. (1955). Undersögelser over bevegelige streptokokker. (Investigation of Motile Streptococci.) Copenhagen: Christtreus Bogtrykkeri.

Quastel, J. H. \& Whetham, M. D. (1924). The equilibria existing between succinic, fumaric, and malic acids in the presence of resting bacteria. Biochem. $J .18,519$.

Shaw, C., Stitt, J. M. \& Cowan, S. T. (1951). Staphylococci and their classification. J. gen. Microbiol. 5, 1010.

Somogyı, M. (1952). Notes on sugar determination. J. biol. Chem. 195, 19.

Williams, R. E. O., Hirch, A. \& Cowan, S. T. (1953). Aerococcus, a new bacterial genus. J. gen. Microbiol. 8, 475. 